Review Article

\title{
THE POTENTIAL ROLE OF GENUS TINOSPORA IN WOUND HEALING: A REVIEW
}

\author{
MICHELE FERNANDEZ, NAVEEN KUMAR SHIVASHEKAREGOWDA, YOW HUI YIN* \\ Centre for Drug Discovery and Molecular Pharmacology, Faculty of Health and Medical Sciences, Taylor's University, Subang Jaya, \\ Selangor, Malaysia \\ *Email: huiyin.yow@taylors.edu.my
}

Received: 20 Apr 2020, Revised and Accepted: 09 Jan 2021

\begin{abstract}
Genus Tinospora has been used in traditional medicine throughout various parts of Asia, particularly in India, China, Thailand, Malaysia and Cambodia. Its ethnomedicinal uses include treatment for fever, cold, oral ulcer, headaches, diarrhoea, diabetes, digestive disorder and rheumatoid arthritis. Some of its ethnomedicinal uses have been justified via scientific studies, include antidiabetic, antioxidant, anti-inflammatory and antimicrobial effects. Recently, several studies have been initiated to investigate the role of Tinospora species in wound healing. This comprehensive review used updated information obtained from systematic literature search using PubMed, Scopus, Science Direct and Google Scholar, to assess the wound healing properties of eleven major Tinospora species namely, T. cordifolia, T. crispa, T. sagittata, T. sinensis, T. bakis, T. craveniana, T. tuberculata, T. capillipes, T. rumphii, T. smilacina, and T. baenzigeri. The information obtained revealed that only T. cordifolia and T. crispa have been reported on its wound-healing abilities. Studies demonstrated that $T$. cordifolia is associated with early re-epithelisation, enhanced tensile strength, increased granulation tissues and increased collagen contents. Whereas T. crispa is reported with wound healing activity through the elevated antioxidant enzymes and inflammation phase. Nevertheless, there is limited evidence on phytochemical constituents from plant extracts that contribute to the wound healing process and their underlying mechanisms. This review deduced the potential gaps for future research aiming to study the genus Tinospora as a potential wound healing agent
\end{abstract}

Keywords: Tinospora, Wound healing, Wound

(C) 2021 The Authors. Published by Innovare Academic Sciences Pvt Ltd. This is an open access article under the CC BY license (https://creativecommons.org/licenses/by/4.0/) DOI: https://dx.doi.org/10.22159/ijpps.2021v13i4.37980. Journal homepage: https://innovareacademics.in/journals/index.php/ijpps.

\section{INTRODUCTION}

A wound is an injury to living tissue by a cut, blow or other impacts, which typically causes the disruption of the normal structure and function of the skin and its architecture [1]. The fundamental response to the injury is wound healing which results in restoration of tissue integrity. Wound healing is a process that consists of four overlapping and continuous phases which are independent of each other. The four phases are coagulation, inflammation, granulation tissue formation and scar tissue formation [1, 2]. For optimal wound healing, the said phases must occur in the proper sequence for a specific duration of time in an optimal condition.

At present, wound management includes medical care such as antibiotic and wound debridement (enzymatic, biologic, surgical and irrigation), topical therapy (growth factors, antiseptic and antimicrobials agents) and wound dressings (film, hydrogel, foam, alginate, hydrocolloids) has been utilised [3]. These measures are meant to improve the wound healing environment and prevent infections [3]. However, there is lacking data to support and justify any of these measures. As such, the need to discover compounds that improve wound healing through intrinsic factors such as oxidative stress and inflammation is crucial.

Unfortunately, drug discovery is a time-consuming and expensive process that involves the identification of new chemical entities (NCEs). NCEs can be discovered through either chemical synthesis (an approach that was found to be less effective in terms of the overall success rate) [4] or by isolating natural compounds. Wound healing activity of plant extracts can be attributed to the antimicrobial, anti-oxidative or free radical scavenging properties and anti-inflammatory activity of the phytoconstituents, as well as mitogenic activity, angiogenesis, collagen production and DNA synthesis, which are induced by their phytoconstituents [5]

Genus Tinospora is of the family Menispermaceae. Plants of this family are twinning and woody climbing herbs and in some rare cases, they are erect upright shrubs or small trees or lianas [6]. The leaves of the plants are petiolate, alternate spiral and the flowers are small and dioecious [6]. The genus Tinospora comprises of 35 species: 7 found in tropical Africa, 3 in southern Africa, 2 in Madagascar and 23 in the Australia, Asia and Pacific region [6]. The current review was based on the hypothesis that the Tinospora family bears a significant amount of bioactive compounds such as alkaloids, phenolic substances and related compounds that possess properties such as antioxidative, anti-inflammatory and mitogenic agent [7]. This review provides an insight into the wound healing studies conducted on the 11 selected Tinospora subspecies over the last $10 \mathrm{y}$ and focused on the crude or alcoholic or chemical extracts of the plants. The available research gaps and the potential of the Tinospora species as a wound healing agent have been identified.

\section{Methodology}

\section{Searching strategies}

Articles were obtained through a systematic literature search in three databases: PubMed, Scopus and Science Direct. Manual search from grey literature, i.e. Google Scholar was also done. The search was conducted for 11 selected Tinospora plants: Tinospora cordifolia Tinospora crispa, Tinospora sagittata, Tinospora sinensis, Tinospora bakis, Tinospora craveniana, Tinospora tuberculata, Tinospora capillipes, Tinospora rumphii, Tinospora smilacina and Tinospora baenzigeri. The keywords or phrases employed to be used in combination with the plant names were wound healing, wound, ulcer, incision, excision and burn.

\section{Inclusion and exclusion criteria}

Studies that were conducted to assess the wound healing abilities of the Tinospora plant family in relation to the skin and were published from January 2009 until October 2020 were included in this review. Wound healing abilities related to the gastrointestinal system, such as peptic ulcer or oral ulcer, were excluded from the review. The search was limited to articles published in the English language only irrespective of the sample size used and/or duration of follow-up. Congress abstracts were also excluded from the review. All articles that studied the included subspecies of the Tinospora family for its wound-healing abilities on an animal model were included so long as the outcomes were clearly documented. Duplicated articles were excluded. 
Table 1: Databases used with respective search terms in the literature search

\begin{tabular}{|c|c|c|}
\hline Database and search terms used to extract all available articles & $\begin{array}{l}\text { No. of articles } \\
\text { retrieved (n) }\end{array}$ & $\begin{array}{l}\text { No. of relevant } \\
\text { articles (n) }\end{array}$ \\
\hline \multicolumn{3}{|l|}{ PubMed } \\
\hline $\begin{array}{l}\text { "tinospora cordifolia" AND/OR “wound” AND/OR “excision” AND/OR “incision” AND/OR "burn AND/OR } \\
\text { "ulcer" AND/OR "wound healing" }\end{array}$ & 506 & 0 \\
\hline $\begin{array}{l}\text { "tinospora crispa" AND/OR “wound" AND/OR “excision” AND/OR “incision” AND/OR "burn AND/OR } \\
\text { "ulcer" AND/OR "wound healing" }\end{array}$ & 77 & 0 \\
\hline $\begin{array}{l}\text { "tinospora sinensis" AND/OR "wound" AND/OR "excision" AND/OR "incision" AND/OR "burn AND/OR } \\
\text { "ulcer" AND/OR "wound healing." }\end{array}$ & 56 & 0 \\
\hline $\begin{array}{l}\text { “tinospora bakis" AND/OR “wound” AND/OR “excision” AND/OR “incision” AND/OR "burn AND/OR } \\
\text { "ulcer" AND/OR "wound healing” }\end{array}$ & 14 & 0 \\
\hline $\begin{array}{l}\text { "tinospora craveniana" AND/OR “wound" AND/OR "excision” AND/OR "incision” AND/OR "burn AND/OR } \\
\text { "ulcer" AND/OR "wound healing" }\end{array}$ & 0 & 0 \\
\hline $\begin{array}{l}\text { "tinospora sagittata" AND/OR “wound" AND/OR "excision” AND/OR "incision" AND/OR "burn AND/OR } \\
\text { "ulcer" AND/OR "wound healing" }\end{array}$ & 16 & 0 \\
\hline $\begin{array}{l}\text { "tinospora tuberculata" AND/OR "wound" AND/OR “excision” AND/OR “incision” AND/OR "burn AND/OR } \\
\text { "ulcer" AND/OR "wound healing" }\end{array}$ & 6 & 0 \\
\hline $\begin{array}{l}\text { "tinospora capillipes" AND/OR “wound" AND/OR "excision" AND/OR “incision” AND/OR "burn AND/OR } \\
\text { "ulcer" AND/OR "wound healing" }\end{array}$ & 4 & 0 \\
\hline $\begin{array}{l}\text { "tinospora smilacina" AND/OR “wound” AND/OR "excision” AND/OR “incision” AND/OR "burn AND/OR } \\
\text { "ulcer" AND/OR "wound healing" }\end{array}$ & 4 & 0 \\
\hline $\begin{array}{l}\text { "tinospora rumphii” AND/OR “wound” AND/OR “excision” AND/OR “incision” AND/OR “burn AND/OR } \\
\text { "ulcer" AND/OR "wound healing” }\end{array}$ & 6 & 0 \\
\hline $\begin{array}{l}\text { "tinospora baenzigeri" AND/OR "wound" AND/OR "excision” AND/OR “incision” AND/OR "burn AND/OR } \\
\text { "ulcer" AND/OR "wound healing" }\end{array}$ & 3 & 0 \\
\hline \multicolumn{3}{|l|}{ Science direct } \\
\hline $\begin{array}{l}\text { "tinospora cordifolia" AND/OR "wound" AND/OR "excision" AND/OR "incision" AND/OR "burn AND/OR } \\
\text { "ulcer" AND/OR "wound healing" }\end{array}$ & 527 & 0 \\
\hline $\begin{array}{l}\text { "tinospora crispa" AND/OR “wound” AND/OR “excision” AND/OR “incision” AND/OR "burn AND/OR } \\
\text { "ulcer" AND/OR "wound healing" }\end{array}$ & 109 & 0 \\
\hline $\begin{array}{l}\text { "tinospora sinensis" AND/OR “wound" AND/OR "excision” AND/OR "incision" AND/OR "burn AND/OR } \\
\text { "ulcer" AND/OR "wound healing" }\end{array}$ & 74 & 0 \\
\hline $\begin{array}{l}\text { "tinospora bakis" AND/OR “wound" AND/OR "excision” AND/OR “incision” AND/OR "burn AND/OR } \\
\text { "ulcer" AND/OR "wound healing" }\end{array}$ & 7 & 0 \\
\hline $\begin{array}{l}\text { "tinospora craveniana" AND/OR "wound" AND/OR “excision” AND/OR “incision" AND/OR "burn AND/OR } \\
\text { "ulcer" AND/OR "wound healing" }\end{array}$ & 2 & 0 \\
\hline $\begin{array}{l}\text { "tinospora sagittata" AND/OR “wound” AND/OR “excision” AND/OR “incision” AND/OR "burn AND/OR } \\
\text { "ulcer" AND/OR "wound healing” }\end{array}$ & 15 & 0 \\
\hline $\begin{array}{l}\text { "tinospora tuberculata" AND/OR "wound" AND/OR “excision" AND/OR "incision” AND/OR "burn AND/OR } \\
\text { "ulcer" AND/OR "wound healing" }\end{array}$ & 8 & 0 \\
\hline $\begin{array}{l}\text { "tinospora capillipes” AND/OR “wound” AND/OR “excision” AND/OR “incision” AND/OR "burn AND/OR } \\
\text { "ulcer" AND/OR "wound healing" }\end{array}$ & 11 & 0 \\
\hline $\begin{array}{l}\text { "tinospora smilacina" AND/OR “wound” AND/OR "excision” AND/OR “incision” AND/OR "burn AND/OR } \\
\text { "ulcer" AND/OR "wound healing" }\end{array}$ & 7 & 0 \\
\hline $\begin{array}{l}\text { "tinospora rumphii" AND/OR "wound" AND/OR “excision” AND/OR “incision” AND/OR “burn AND/OR } \\
\text { "ulcer" AND/OR "wound healing" }\end{array}$ & 16 & 0 \\
\hline $\begin{array}{l}\text { "tinospora baenzigeri" AND/OR "wound" AND/OR “excision” AND/OR “incision” AND/OR "burn AND/OR } \\
\text { "ulcer" AND/OR "wound healing" }\end{array}$ & 0 & 0 \\
\hline \multicolumn{3}{|l|}{ Scopus } \\
\hline $\begin{array}{l}\text { "tinospora cordifolia" AND/OR “wound" AND/OR “excision” AND/OR “incision” AND/OR "burn AND/OR } \\
\text { "ulcer" AND/OR "wound healing" }\end{array}$ & 999 & 12 \\
\hline $\begin{array}{l}\text { "tinospora crispa" AND/OR “wound" AND/OR “excision” AND/OR “incision” AND/OR "burn AND/OR } \\
\text { "ulcer" AND/OR "wound healing” }\end{array}$ & 158 & 8 \\
\hline $\begin{array}{l}\text { "tinospora sinensis" AND/OR “wound" AND/OR "excision” AND/OR “incision" AND/OR "burn AND/OR } \\
\text { "ulcer" AND/OR "wound healing” }\end{array}$ & 44 & 0 \\
\hline $\begin{array}{l}\text { "tinospora bakis" AND/OR “wound" AND/OR “excision” AND/OR “incision” AND/OR "burn AND/OR } \\
\text { "ulcer" AND/OR "wound healing" }\end{array}$ & 5 & 0 \\
\hline $\begin{array}{l}\text { "tinospora craveniana” AND/OR "wound" AND/OR “excision” AND/OR “incision” AND/OR “burn AND/OR } \\
\text { "ulcer" AND/OR "wound healing" }\end{array}$ & 0 & 0 \\
\hline $\begin{array}{l}\text { "tinospora sagittata" AND/OR “wound” AND/OR “excision” AND/OR “incision” AND/OR “burn AND/OR } \\
\text { "ulcer" AND/OR "wound healing” }\end{array}$ & 19 & 0 \\
\hline $\begin{array}{l}\text { "tinospora tuberculata" AND/OR "wound" AND/OR "excision” AND/OR "incision” AND/OR "burn AND/OR } \\
\text { "ulcer" AND/OR "wound healing" }\end{array}$ & 8 & 0 \\
\hline $\begin{array}{l}\text { "tinospora capillipes" AND/OR “wound" AND/OR "excision” AND/OR “incision” AND/OR "burn AND/OR } \\
\text { "ulcer" AND/OR “wound healing” }\end{array}$ & 5 & 0 \\
\hline $\begin{array}{l}\text { "tinospora smilacina" AND/OR “wound" AND/OR "excision” AND/OR “incision” AND/OR "burn AND/OR } \\
\text { "ulcer" AND/OR "wound healing" }\end{array}$ & 4 & 0 \\
\hline $\begin{array}{l}\text { “tinospora rumphii” AND/OR “wound” AND/OR “excision” AND/OR “incision” AND/OR “burn AND/OR } \\
\text { "ulcer" AND/OR "wound healing” }\end{array}$ & 6 & 0 \\
\hline $\begin{array}{l}\text { "tinospora baenzigeri" AND/OR "wound" AND/OR "excision" AND/OR "incision" AND/OR "burn AND/OR } \\
\text { "ulcer" AND/OR "wound healing" } \\
\text { Google scholar }\end{array}$ & 4 & 0 \\
\hline
\end{tabular}




\begin{tabular}{|c|c|c|}
\hline $\begin{array}{l}\text { "tinospora cordifolia" AND/OR “wound” AND/OR “excision” AND/OR “incision” AND/OR "burn AND/OR } \\
\text { "ulcer" AND/OR "wound healing" }\end{array}$ & 7592 & 56 \\
\hline $\begin{array}{l}\text { "tinospora crispa" AND/OR "wound" AND/OR "excision” AND/OR "incision” AND/OR "burn AND/OR } \\
\text { "ulcer" AND/OR "wound healing" }\end{array}$ & 908 & 16 \\
\hline $\begin{array}{l}\text { "tinospora sinensis" AND/OR “wound" AND/OR "excision" AND/OR "incision" AND/OR "burn AND/OR } \\
\text { "ulcer" AND/OR "wound healing" }\end{array}$ & 530 & 1 \\
\hline $\begin{array}{l}\text { "tinospora bakis" AND/OR “wound” AND/OR “excision” AND/OR “incision” AND/OR "burn AND/OR } \\
\text { "ulcer" AND/OR "wound healing" }\end{array}$ & 62 & 0 \\
\hline $\begin{array}{l}\text { "tinospora craveniana" AND/OR "wound" AND/OR "excision" AND/OR "incision" AND/OR "burn AND/OR } \\
\text { "ulcer" AND/OR "wound healing" }\end{array}$ & 5 & 0 \\
\hline $\begin{array}{l}\text { "tinospora sagittata” AND/OR “wound” AND/OR “excision” AND/OR “incision” AND/OR "burn AND/OR } \\
\text { "ulcer" AND/OR "wound healing” }\end{array}$ & 129 & 0 \\
\hline $\begin{array}{l}\text { "tinospora tuberculata" AND/OR "wound" AND/OR "excision" AND/OR "incision" AND/OR "burn AND/OR } \\
\text { "ulcer" AND/OR "wound healing" }\end{array}$ & 73 & 0 \\
\hline $\begin{array}{l}\text { "tinospora capillipes" AND/OR “wound" AND/OR "excision" AND/OR “incision” AND/OR "burn AND/OR } \\
\text { "ulcer" AND/OR "wound healing" }\end{array}$ & 39 & 0 \\
\hline $\begin{array}{l}\text { "tinospora smilacina” AND/OR “wound” AND/OR "excision” AND/OR “incision” AND/OR "burn AND/OR } \\
\text { "ulcer" AND/OR "wound healing” }\end{array}$ & 54 & 0 \\
\hline $\begin{array}{l}\text { "tinospora rumphii" AND/OR “wound” AND/OR “excision” AND/OR “incision” AND/OR "burn AND/OR } \\
\text { "ulcer" AND/OR "wound healing" }\end{array}$ & 96 & 0 \\
\hline $\begin{array}{l}\text { "tinospora baenzigeri" AND/OR "wound" AND/OR “excision” AND/OR “incision” AND/OR "burn AND/OR } \\
\text { "ulcer" AND/OR "wound healing" }\end{array}$ & 7 & 0 \\
\hline
\end{tabular}

\section{Data extraction and synthesis}

Initial screening of the articles was reviewed by researchers from the title, abstract and full text. Articles that met the predefined inclusion and exclusion criteria were selected and included in the study. Data were then extracted from the articles and tabulated into tables to assemble the appropriate information on study design, intervention and treatment outcomes.

\section{RESULTS}

In the present review, a total of 12213 number of articles were retrieved from different sources related to wound healing abilities of Tinospora family (table 1). Of the retrieved articles, 61 articles met the inclusion criteria stated in the methodology (fig. 1). Upon excluding the duplicated articles and 1 congress abstract, 11 of the scientific articles were found to be relevant and data from the articles were included in this article. Based on the retrieved data over the last $10 \mathrm{y}$, only two of the 11 species of Tinospora, namely Tinospora cordifolia and Tinospora crispa were studied for its wound-healing abilities.

\section{Tinospora cordifolia}

Based on the search done with the aforementioned methodology, eight papers reported on the wound healing properties of $T$. cordifolia (table 2). Studies have been done on topical treatment [811 with doses ranging from $1 \%$ to $10 \%$, in either cream or ointment bases, as well as oral treatment [12-15] with doses ranging from 200 $\mathrm{mg} / \mathrm{kg}$ to $600 \mathrm{mg} / \mathrm{kg}$

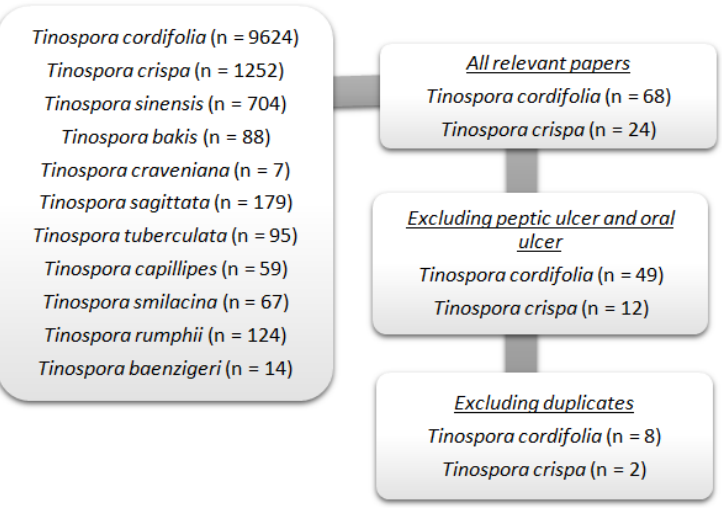

Fig. 1: Flow chart of the article screening phase based on the inclusion and exclusion criteria

Table 2: Summary of wound healing studies involving Tinospora cordifolia conducted between 2009 to 2020

\begin{tabular}{|c|c|c|c|c|c|}
\hline $\begin{array}{l}\text { Part of } \\
\text { plant }\end{array}$ & $\begin{array}{l}\text { Solvent/extractio } \\
n \text { method }\end{array}$ & $\begin{array}{l}\text { Wound model } \\
\text { and animal } \\
\text { used }\end{array}$ & Treatment & Findings & Reference \\
\hline Leaf & $\begin{array}{l}\text { Methanol, } \\
\text { Maceration }\end{array}$ & $\begin{array}{l}\text { Excision and } \\
\text { incision wound } \\
\text { model on male } \\
\text { Sprague Dawley } \\
\text { rats }\end{array}$ & $\begin{array}{l}5 \% \text { ointment } \\
\text { (base: } \\
\text { Vaseline), BD, } \\
28 \mathrm{~d}\end{array}$ & $\begin{array}{l}\text { Early reepithelisation and faster wound closure is possibly } \\
\text { associated with increased keratinocyte proliferation and } \\
\text { migration to the wound surface. } \\
\text { An increase in tensile strength was also noted. } \\
\text { Proliferation of fibrous connective tissue and angiogenesis was } \\
\text { noted. } \\
\text { Polymorph nuclear lymphocytes were detected on day } 21 \text { of the } \\
\text { treatment. }\end{array}$ & [8] \\
\hline Leaf & $\begin{array}{l}\text { Petroleum ether, } \\
\text { ethanol, water, } \\
\text { Soxhlet extraction }\end{array}$ & $\begin{array}{l}\text { Dead space, } \\
\text { excision and } \\
\text { incision wound } \\
\text { model on either } \\
\text { sex of albino } \\
\text { Wistar rats }\end{array}$ & $\begin{array}{l}200 \mathrm{mg} / \mathrm{kg}, \\
\mathrm{OD}, 16 \mathrm{~d}\end{array}$ & $\begin{array}{l}\text { Complete epithelisation and percentage of wound closure were } \\
\text { the highest in the ethanol extract-treated group. } \\
\text { Increased tensile strength noted in the ethanol extract-treated } \\
\text { group, followed by the aqueous treated group, but was less in } \\
\text { the petroleum ether extract-treated group. } \\
\text { Ethanol and aqueous extracts shown increased regenerated } \\
\text { tissue, epithelialization, fibroblasts and revascularisation. }\end{array}$ & [12] \\
\hline- & - & $\begin{array}{l}\text { Resutured } \\
\text { incision wound, } \\
\text { dead space } \\
\text { wound on male }\end{array}$ & $\begin{array}{l}200 \mathrm{mg} / \mathrm{kg} \\
\text { (base: } 2 \% \\
\text { gum acacia) } \\
\text { OD, } 10 \mathrm{~d}\end{array}$ & $\begin{array}{l}\text { Significant increase in tensile strength in resutured incision } \\
\text { wound } \\
\text { Histology of TC treated dead space wound shown an increase in } \\
\text { the number of fibroblasts, thick bundles of collagen tissue }\end{array}$ & [13] \\
\hline
\end{tabular}




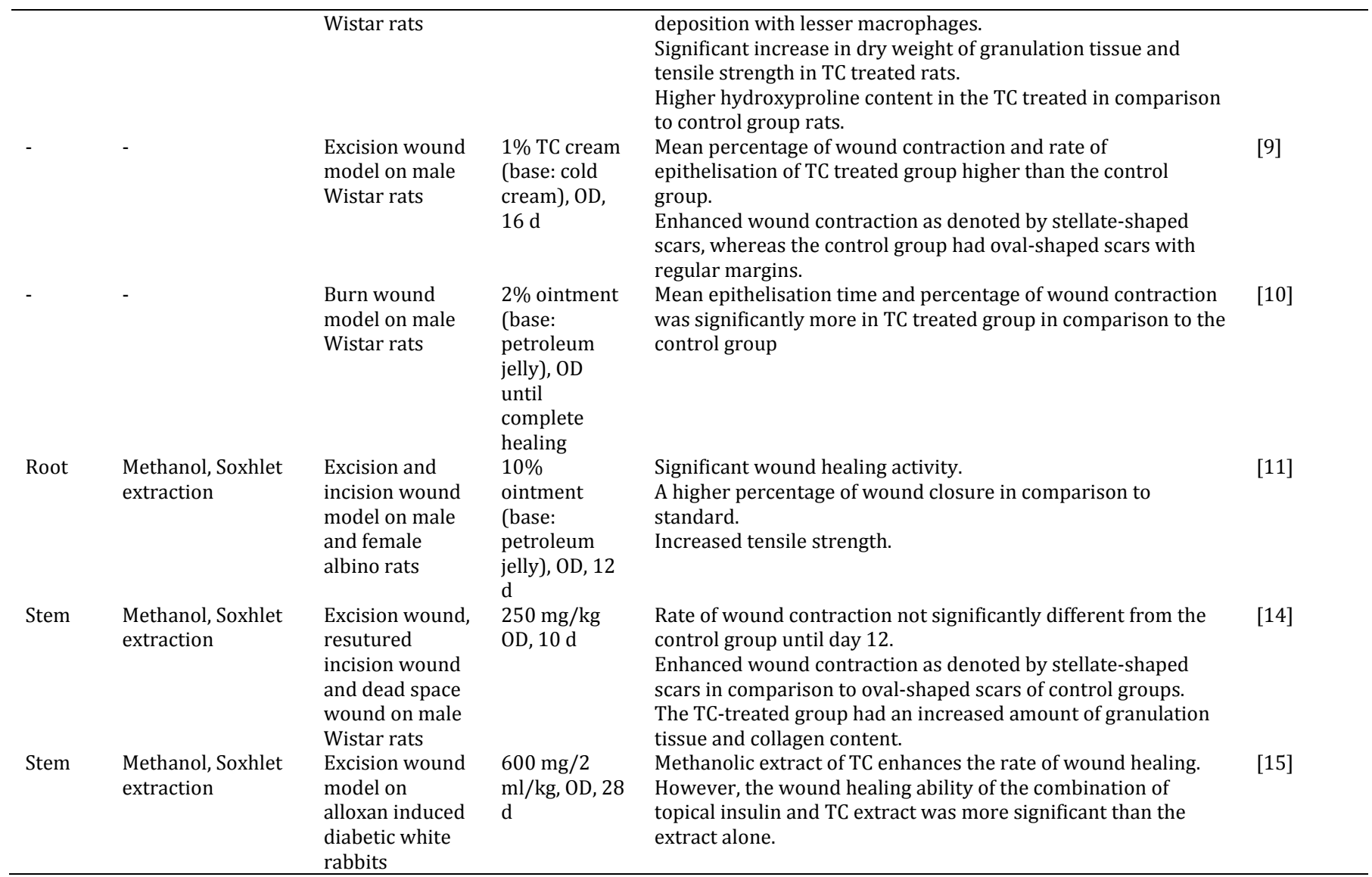

TC: T. cordifolia.

Almost every study used the excision and incision wound model [8, 9, 11-14]. Only two studies were done on the dead space wound model $[12,13]$, one on the burn wound model [10] and one on the diabetic wound model [15]. All the studies indicated that $T$. cordifolia extracts have positive effects on wound healing in terms of the wound contraction rate, tensile strength and histopathology of the skin. Two studies included the estimation of hydroxyproline, a basic constituent of collagen and an important constituent of extracellular matrix healing $[12,13]$.

Based on the parameters observed, the use of T. cordifolia is found to hasten wound healing $[8,11,12,14,15]$; early re-epithelisation which is associated with increased keratinocyte proliferation and migration to wound surface [8], increased tensile strength [8, 11-13]. T. cordifolia-treated groups also exhibited an increased amount of granulation tissue which indicates higher protein content $[13,14]$ and increased collagen content which is indicated by the increased amount of hydroxyproline [12,13].

The studies also investigated the histology of granulation tissue and wound site to further strengthen the claims of T. cordifolia's wound healing potential. The most commonly used stain was haematoxylin and eosin $[8,11,13-15]$. One study employed van Gieson's staining [14]. The histology results shown that topical treatment of $T$. cordifolia enables the epidermis to be fully formed within $12 \mathrm{~d}$ of treatment with $10 \%$ ointment once daily [11]. Furthermore, it also enhanced collagen formation [11]. Barua et al. applied the same model with different dose (i.e. $5 \%$ ointment twice daily) and shown that there was proliferation of fibrous connective tissue with increase angiogenesis and increased collagen maturation by cross linking on day 21 of treatment [8]. However, the study also reported that there was still polymorph nuclear lymphocyte infiltration at the wound site of the T. cordifolia-treated group, indicating that wound healing was not complete yet [8]
Orally treated animals also shown positive wound healing activities. Van Gieson staining of granulation tissues of rats treated with the ethanol extract of $T$. cordifolia depicted an increase in collagen formation and lesser macrophages [12]. Similarly, methanol extracttreated rats also reported positive results [14] on haematoxylin and eosin staining with an increase in granulation tissue and increased cell proliferation with lymphocytes and macrophages, whereas Van Gieson staining shown a marked increase in collagen content in comparison to the control group. In a different study, methanol extract-treated rats had a scanty amount of granulation tissues with a maximum amount of fibrocollagen tissue in comparison to control, which had abundant granulation tissue and scanty fibrocollagen tissue [13]. 28-day old diabetic wounds from white rabbits did not have properly formed epidermis and had mild tissue reactions with few fibrous and collagen tissues. Scanning Electron Microscopy study of diabetic wounds from white rabbits treated with 600 $\mathrm{mg} / \mathrm{kg} /$ day methanolic extract of $T$. cordifolia illustrated that on day 14, there was irregularly arranged collagenous tissue along with numerous newly formed blood vessels in the wound samples. On day 28, although the collagenous tissue became denser and was arranged in more regular form, the epithelial layer was not completely formed and angiogenesis was reduced but still present [15].

\section{Tinospora crispa}

In the last $10 \mathrm{y}$, only three papers have reported on the wound healing ability of T. crispa (table 3). Two papers reported on the wound healing ability of the excision wound model $[16,17]$. All two papers reported that T. crispa extract has positive wound healing properties. The studies conducted assessed the wound healing ability of the herb as a topical treatment: $5 \%$ ointment OD [17] or $100 \mathrm{mg} / \mathrm{ml}$ or $200 \mathrm{mg} / \mathrm{ml}$ intrasite gel BD [16]. 
Table 3: Wound healing studies involving Tinospora crispa conducted between 2009 to 2020

\begin{tabular}{|c|c|c|c|c|c|}
\hline $\begin{array}{l}\text { Part of } \\
\text { plant }\end{array}$ & $\begin{array}{l}\text { Solvent/extraction } \\
\text { method }\end{array}$ & Model & Treatment & Findings & Reference \\
\hline Stem & $\begin{array}{l}\text { Methanol and } \\
\text { chloroform, } \\
\text { Maceration }\end{array}$ & $\begin{array}{l}\text { Excision } \\
\text { wound model } \\
\text { on albino rats } \\
\text { of either sex }\end{array}$ & $\begin{array}{l}5 \% \text { ointment (base: } \\
\text { simple ointment), OD, } \\
17 \mathrm{~d}\end{array}$ & $\begin{array}{l}\text { Better wound healing activity was observed in } \\
\text { the methanolic fraction in comparison to the } \\
\text { chloroform fraction. } \\
\text { Accelerated wound closure may be associated } \\
\text { with increased keratinocyte proliferation and } \\
\text { their migration to the surface. }\end{array}$ & [17] \\
\hline Stem & $\begin{array}{l}95 \% \text { ethanol, } \\
\text { maceration }\end{array}$ & $\begin{array}{l}\text { Excision } \\
\text { wound on } \\
\text { female } \\
\text { Sprague } \\
\text { Dawley rats }\end{array}$ & $\begin{array}{l}100 \mathrm{mg} / \mathrm{ml} \text { and } 200 \\
\mathrm{mg} / \mathrm{ml} \text { (base: } 2 \% \text { gum } \\
\text { acacia), BD, } 15 \mathrm{~d}\end{array}$ & $\begin{array}{l}\text { Significant wound healing action is seen } \\
\text { through the improved activity of endogenous } \\
\text { antioxidants: SOD and CAT that prevent free- } \\
\text { radical mediated tissue injury. } \\
\text { Rapid movement to the proliferative phase and } \\
\text { shortened inflammatory phase helped enhance } \\
\text { wound contraction. }\end{array}$ & [16] \\
\hline
\end{tabular}

SOD: superoxide dismutase; CAT: catalase.

Only one study reported on the wound contraction rate of $T$. crispa. Vijendren and colleagues reported that T. crispa extract hastened wound contraction and the rate was consistent with the Betadinetreated group [17]. Besides that, the study demonstrated that methanol fraction $(100 \%)$ had a higher wound contraction percentage than chloroform fraction (96.46\%) [17]. In term of histopathology, the haematoxylin and eosin-stained granulation tissue of the rat treated with $100 \mathrm{mg} / \mathrm{ml}$ and $200 \mathrm{mg} / \mathrm{ml}$ for $15 \mathrm{~d}$ demonstrated comparatively less inflammatory cells and more collagen, fibroblast and blood proliferating capillaries in comparison to the control group. Scabs were also noted in the slides [16]. For the wound healing ability of T. crispa, one study has conducted biochemical analysis of the skin wound site. Biochemical analysis of antioxidant enzymes shown elevated superoxide dismutase (SOD) level, catalase (CAT) level and significantly lowered malondialdehyde level among T. crispa-treated rats, in comparison to the vehicle treated group. As for the levels of inflammatory cytokines, the study demonstrated significantly elevated TGF- $\beta 1$ in the treated group compared to vehicle control and intrasite geltreated group and significantly lowered TGF- $\alpha$ in treated group compared to vehicle control group [16].

\section{DISCUSSION}

There are many factors which may affect wound healing through one or more phases of the wound healing process, thus causing improper or impaired wound healing. Such wounds frequently enter a state of pathologic inflammation due to an uncoordinated wound healing process. These factors can be categorised into local and systemic factors. Local factors include oxygenation, infection, foreign body, and venous insufficiency directly influence the characteristics of the wound. On the other hand, systemic factors are those factors that associated overall health or disease state of the individual that affect the ability of the wound to heal, such as age, gender, stress, ischaemia, diseases, obesity, the use of medication, alcoholism, smoking, nutrition, and immunocompromised conditions [18]. Plants have immense potential when it comes to the management and treatment of wounds. In the past, many plants were known to be used by tribal and traditional medicine practitioners for the treatment of wounds. The natural agents induce wound healing through mechanisms such as antimicrobial, anti-inflammatory, and antioxidant activities. As phytomedicine is not only affordable but also safe, it has been a great interest to scientists to discover new effective drugs [19].

T. cordifolia (Menispermaceae) or more commonly known as "Guduchi" in Sanskrit is a large, perennial, deciduous climbing shrub of weak and fleshy steam with greenish-yellow typical flowers that are commonly found at higher altitudes [5, 20]. In Ayurveda, $T$. cordifolia is known for its immense application in the treatment of many diseases. Today, it is clinically used by many patients as it is available as either a single herbal drug or in formulations [21]. Traditionally, the leaves and stems of $T$. cordifolia are used to treat rheumatism, fever, jaundice, cough, eye disease and diabetes [22-25], whereas the root is used to treat vomiting [22]. It is also known to be used to treat skin diseases and to be an anti-poison and antibacterial [25]. Scientifically, T. cordifolia has been demonstrated to have anti-cancer activity [26-28], the ability to enhance cognition and memory, anti-inflammatory and wound healing activity $[10,14,29]$, anti-malaria activity [30] and antifungal [31].

Over recent years, the wound healing ability of $T$. cordifolia has been explored. Studies have been demonstrated the potential wound healing ability of $T$. cordifolia on different wound models with different formulations and dosages, either in topical (1\% to $10 \%)$ or oral $(200 \mathrm{mg} / \mathrm{kg}$ to $600 \mathrm{mg} / \mathrm{kg})$ route of administration. The dosage used was within the safe dose range. Acute toxicity tests conducted in different studies shown that no toxicity nor death was noted at doses above $3 \mathrm{~g} / \mathrm{kg}$ of ethanolic and aqueous extracts [32-34] and 5 $\mathrm{g} / \mathrm{kg}$ of methanolic T. cordifolia extract [8]. Additionally, up to 200 $\mathrm{mg} / \mathrm{kg}$ of chloroformic extract of T. cordifolia did not show visible signs of toxicity in short term treatment [34]. Long term treatment (60 d) of $400 \mathrm{mg} / \mathrm{kg} \mathrm{T}$. cordifolia aqueous extract shown no effect on red blood cell count, white blood cell count, haemoglobin levels and haemotocrit levels [33]. A clinical study reported that when $T$. cordifolia was administered at a dose of $500 \mathrm{mg}$ /day for $21 \mathrm{~d}$ in healthy individuals, it did not exert any remarkable adverse effects on the cardiovascular system, central nervous system, renal system and gastrointestinal system [20].

In term of wound healing model, wound healing activities of $T$. cordifolia was demonstrated to be potent in normal wounds and it was not as potent in diabetic wounds [15]. It was found to hasten wound healing via early reepithelisation, increased tensile strength, increased granulation tissue and collagen content in normal wound models [8, 11-14]. In the diabetic wound model, the epidermis layer was not properly formed for a 28-day old diabetic wound with few fibrous and collagen tissues [15]. This shown that, though oral $T$. cordifolia may not be an effective treatment on its own for diabetic wounds, however, when used together with topical insulin, it may synergistically help to improve diabetic wound healing [15].

On the other hand, the method of extraction and solvent used may influence the wound healing ability of T. cordifolia. Rani and colleagues reported that the ethanolic extract of T. cordifolia leaves and stem had the highest percentage of wound contraction, rate of epithelisation, highest collagen content and tensile strength in comparison to aqueous and petroleum ether extracts. This might be attributed to phytochemical content in ethanolic extracts of the leaf, which contains alkaloids, amino acids, carbohydrates, cardiac glycosides, flavonoids, phenols, tannins and terpenoids, whereas the stem contains the same compounds except for carbohydrates and cardiac glycosides [35]. Methanol is the common solvent used in the extraction of phytochemicals from T. cordifolia. However, as studies have indicated that its ethanolic extract is known the have higher concentrations of high levels of phenols and flavonoids [36-38], a study to compare the wound healing ability of methanolic and ethanolic extract of T. cordifolia would be helpful to understand which fraction of extract has better wound healing properties. 
T. crispa (Menispermaceae) is an herbaceous woody vine with shiny green leaves that grows in the tropical and subtropical regions of Southeast Asia: India, Malaysia, Philippines, Indonesia, Thailand and Vietnam [39]. It is commonly known as "Patawali" or "Seruntum" in Malaysia, "Brotawali" or "Andawali" in Indonesia, "Makabuhay" in the Philippines and "Boraphet" in Thailand [39]. It is a popular herb used traditional medicine in the treatment of diabetes mellitus in Malaysia, Thailand and the Martinique Island [39]. It is also used as anti-pyretic, anti-inflammatory and anti-malarial in Thai traditional medicine [40]. In Chinese traditional medicine, the herb is also used as treatment for fever and scabies, tropical ulcer related disorders, fractures and septicaemia [40]. Besides this, the herb is also used for the treatment of rheumatism, hypertension, tuberculosis and diarrhoea [39[. Oral administration of the decoction of the stem of the herb is claimed to possess anti-malarial and anti-helminthic properties [40]. The poultice of fresh leaves, on the other hand, is reported to be used for the treatment of wounds and itches [40]. Scientifically, many of the ethnopharmacological claims of T. crispa have been proven. However, its claim as a wound healing agent has not been extensively studied nor reported.

Similarly, the potential wound healing ability of T. crispa has been studied on different wound models with different formulations and dosages. Studies have been demonstrated the potential wound healing ability of T. crispa on different wound models with different formulations and dosages, either in topical (5\% ointment; 100 $\mathrm{mg} / \mathrm{ml}$ and $200 \mathrm{mg} / \mathrm{ml}$ intrasite gel) or oral $(250 \mathrm{mg} / \mathrm{kg})$ route of administration. Acute toxicity test of $T$. crispa done in the past shown that there was no death nor toxic signs up to the dose of 2 $\mathrm{g} / \mathrm{kg}$ [16]. Other acute toxicity studies shown that, at the highest dose of $4 \mathrm{~g} / \mathrm{kg}$ of $T$. crispa ethanolic extract, there were no toxic signs $[39,41]$. However, chronic toxicity study of 6 mo shown that the administration of ethanolic extract of T. crispa at a dose of 9.26 $\mathrm{g} / \mathrm{kg} /$ day to rats causes renal and hepatic toxicity [39]. A more recent study revealed that the ethanolic extract of $T$. crispa contained certain hepatotoxins which potentiated thioacetamideinduced hepatotoxicity in rats when 100 and $200 \mathrm{mg} / \mathrm{kg}$ of the extract was administered for $8 \mathrm{w}$ [42].

As for T. crispa, the wound healing studies conducted used only the stem of the plant but studied the effects of extracts from three different solvents: ethanol, methanol and chloroform. Methanolic extract was reported to have better wound healing properties than chloroform extract [17]. Unfortunately, there are no reported studies conducted to compare the efficacy between the ethanolic and methanolic extracts. Methanolic stem extracts of T. crispa are known to contain alkaloids, steroids, saponosides, flavonoids, tannins, phenols and terpenoids [43]. The information on the phytochemicals in ethanol extracts on the other hand had not been analysed yet.

The enhanced wound healing potency of the plant extracts may be attributed to its antioxidative action. Oxidative stress occurs when there is an imbalance of free radicals and antioxidants in the body. At a high concentration, reactive oxygen species induces severe tissue damage and even leads to neoplastic transformation, this further impedes wound healing by causing damage to cellular membranes, DNA, proteins, as well as lipids. High oxidative stress would therefore cause damage to the growing tissue at the repair site. Antioxidants act as oxygen scavengers by reacting with free radicals and chelating catalytic metals. Asides from this, lipid peroxidation levels would be reduced following by the reduced oxidative stress. Reduced lipid peroxidation levels increase the viability of collagen fibrils by increasing the strength of collagen fibres, improving the circulation, preventing cell damage, and promoting DNA synthesis. Therefore, by reducing oxidative stress, reepithelisation time is expected to be reduced [19].

T. cordifolia was reported to possess strong free radical scavenging properties against superoxide anions $\left(\mathrm{O}_{2}^{-}\right)$, nitric oxide radicals, hydroxyl radicals $(\mathrm{OH})$ and peroxynitrite anion (ONOO-) [44]. A study comparing the antioxidative potential of different T. cordifolia stem and leaf extracts with methanol, acetone, water, chloroform, ethyl acetate and hexane, reported that among leaf extracts, methanol shown the highest inhibition (70.25\%), whereas amongst stem extracts, ethyl acetate shown the highest inhibition $(85.45 \%)$ of carbonyl modification of protein (PCO) [45]. The assessment of
PCO is a widely used marker for oxidative protein modification and it is a sensitive early marker of oxidative stress to tissues as compared with lipid peroxidation [46]. Another study indicated that the ethanol extract of $T$. cordifolia stem which contains substantial amounts of phenols also has marked antioxidant activity [47]. The antioxidative activity of T. cordifolia is credited to its alkaloids and diterpenoid lactones such (-)epicatechin, tinosporin, isocolumbin and palmatine [48,49]. Consistently, T. crispa also possesses antioxidative activity. The antioxidative potency of aqueous extract of $T$. crispa stem is equivalent to establish antioxidants such as butylhydroxy toluene and vitamin C [50]. It was reported that methanol extract of the stem has the strongest antioxidant potential between aqueous, methanol and chloroform extracts of T. crispa stem, which potentially due to the phenolic compounds presented in the extract [51]. Besides this, it is known that the antioxidant and free-radical scavenging potency of $\mathrm{N}$-trans-feruloyltyramine, $\mathrm{N}$-cisferuloyltyramine and secoisolariciresinol which were isolated from the dichloromethane extract of T. crispa is higher than of butylhydroxy toluene [52].

In the case of chronic wounds, due to a myriad of factors which can delay wound healing-chronic diseases, diabetes, vascular insufficiency, malnutrition, ageing, and local factors, the damaged tissue is detained in a prolonged and heightened inflammatory state [53]. While inflammation is essential in wound healing for clearing the debris and infection, prolonged inflammation can result in delayed wound healing and increased scarring [54]. During the inflammatory phase, macrophages secrete effector molecules such as nitric oxide (NO), prostaglandin (PG) $\mathrm{E}_{2}$, tumour necrosis factor- $\alpha$ (TNF- $\alpha$ ), interleukin (IL)-1 $\beta$, and IL-6 [55]. NO, which is released by the inducible nitric oxide synthase (iNOS), functions as an antimicrobial agent and a regulator of inflammatory reactions [56]. TNF- $\alpha$ is known to promote tissue fibrosis and also synthesis of collagenases and adhesion molecule. Whereas IL-6 recruits inflammatory cells, especially neutrophils. The crosstalk between iNOS and TNF- $\alpha$ regulates the secretion of another proinflammatory cytokine, $\mathrm{PGE}_{2}$, which exerts vasodilation, pain, and cellular proliferation at the site of inflammation $[57,58]$. The persistent upregulation of these cytokines prolongs inflammation, hence, agents that downregulate their production are valuable in the treatment of chronic inflammation.

In the case of $T$. cordifolia, chloroform extract was reported significantly lowered levels of inflammatory cytokines such as PGE2, IL-1 $\beta$ and IL-6. The study also proved that chloroform extract of $T$. cordifolia downregulated both bacterial lipopolysaccharide (LPS) induced transcription and translation of proinflammatory biomarkers such as TNF- $\alpha$, COX- 2 and iNOS dose-dependently, whereas COX-1 gene expression was observed to be similar to that of normal control [59]. The study indicated that the possible phytochemicals responsible for this action could be stigmasterol and $\beta$-sitosterol [59]. Furthermore, the aqueous extract of T. cordifolia was also reported to be significantly reduced the production of NO and downregulated gene expression of TNF- $\alpha$ and COX-2. Besides this, the extract also inhibited the gene expression of toll-like receptor 4 [60], which is an important regulator of wound inflammation [61]. However, the aqueous extract of $T$. cordifolia only significantly inhibited IL- $\beta$ at higher concentrations of $250-500 \mu \mathrm{g} / \mathrm{ml}$. The study also reported that tinosporaside significantly reduced NO production [60]. Asides from this, the anti-inflammatory activity of T. cordifolia is also credited to its alkaloids: berberine, jatorrhizine, magnoflorine, palmatine and isocolumbin, glycosides; cordifolioside A, cordioside and syringin, steroids; ecdysterone diterpenoid lactones; furanolactone, tinosporin, tinosporide, jateorine, columbin and clerodane derivatives $[15,48]$. In T. crispa, cordioside, quercetin, paullinic acid, and boldine, are the phytochemicals known to possess anti-inflammatory activity [62]. The latter phytochemicals improved intracellular expression of cytokines such as INF- $\gamma$, IL-6, and IL-8 [62]. Tinocrisposide, a compound isolated from $T$. crispa, on the other hand, was reported to inhibit the formation of NO in LPS induced RAW 264.7 cells in a dose-dependent manner [63]. However, there is limited studies conducted to assess wound healing ability of these phytochemicals independently.

The common parameters analysed in wound healing studies for these plants mostly are physical parameters such as wound contraction rate, 
tensile strength and histopathology. In terms of biochemical parameters studied, T. crispa has more biochemical parameters studied compared to T. cordifolia. Thus far, the biochemical parameters studied have been the estimation of hydroxyproline, SOD levels and CAT levels. However, many other parameters that can be studied to understand the underlying mechanisms by which the extract improves wound healing. These includes the estimation of hexosamine [64] and expression of matrix metalloproteins (MMPs) such as MMP-2, MMP-8 and MMP-9 [65]. Increased hexosamine content reflects the stabilisation of collagen molecules by enhancing the electrostatic and ionic interaction [64]. MMPs play an important role in regulating extracellular matrix degradation and deposition which is essential for wound reepithelialisation. However, for successful wound healing, timed expression and activation of MMPs in response to wounding is important [65]. By studying the expression of MMPs, we can better understand the wound healing mechanism of the extract or phytochemical. More molecular studies on the mechanisms affected by the extract or phytochemicals in wound healing is needed in the future research.

\section{Research gaps in study}

Out of the 11 species from the Tinospora genus, only two species, notably T. cordifolia and T. crispa have been explored on their wound healing abilities. However, in comparison to T. cordifolia, there are very scarce and limited articles on wound healing abilities of T. crispa. The effect of other species in wound healing remains unknown. Based on the literature, positive results have been reported regardless of the part of plants or solvent used for extraction in both species. T. crispa studies did not address the superiority in wound healing ability between the different types of solvent used for extraction or different parts of the plant used. Furthermore, although various phytochemicals of Tinospora species had been reported to possess antioxidants and anti-inflammatory effects, there are limited studies conducted to assess the wound healing ability of these phytochemicals independently. Hence, the exact phytochemical constituents in the plant extracts that contribute to hastened wound healing is unclear. This inevitably also entails that the underlying molecular mechanisms of these extracts or phytochemicals in wound healing have not been elucidated. More research is needed to elucidate the molecular mechanism of action of the extracts or phytochemicals responsible in improving wound healing process.

\section{CONCLUSION}

Based on the literature review, in the family of Tinospora, two out of 11 of selected species have been studied for its wound healing abilities. Scientific research has shown that both T. cordifolia and T. crispa possess significant wound healing abilities regardless of the part of the plants, extraction methods and wound models used. Although various phytochemicals of Tinospora species had been reported to possess antioxidants and anti-inflammatory effects, there are limited studies conducted to assess the wound healing ability of these phytochemicals independently. Inevitably, the underlying molecular mechanisms of these extracts or phytochemicals in would healing have not elucidated yet. Therefore, more in-depth research is required in the future to elucidate the phytochemicals responsible and its mechanism of action on chronic and acute wound healing.

\section{ABBREVIATIONS}

NCE: new chemical entities, TC: Tinospora cordifolia, SOD: superoxide dismutase, CAT: catalase, PCO: carbonyl modification of protein, NO: nitric oxide, PGE2: prostaglandin E2, TNF- $\alpha$ : tumour necrosis factor- $\alpha$, IL-1 $\beta$ : interleukin-1 $\beta$, IL-6: interleukin-6, iNOS: inducible nitric oxide synthase, LPS: lipopolysaccharide, MMP: matrix metalloproteins

\section{FUNDING}

This study was sponsored by Taylor's University (TRGS/ERFS/1/2018/SOP/033). Taylor's University provided financial support but had no influence on the content of the work.

\section{AUTHORS CONTRIBUTIONS}

We declare that this work was done by the authors named in this article and all liabilities pertaining to claims relating to the content of this article will be borne by them. MF, YHY and NKS developed the idea to review the topic. YHY and NKS coordinated the research activities. MF performed the literature search, data analysis and manuscript preparation. YHY and NKS reviewed the literature review. All authors read and approved the manuscript.

\section{CONFLICT OF INTERESTS}

Declared none

\section{REFERENCES}

1. Demidova Rice TN, Hamblin MR, Herman IM. Acute and impaired wound healing: pathophysiology and current methods for drug delivery, part 1: normal and chronic wounds: biology, causes, and approaches to care. Adv Skin Wound Care 2012;25:304-14.

2. Gosain A, DiPietro LA. Aging and wound healing. World J Surg 2004;28:321-6.

3. Atiyeh BS, Ioannovich J, Al-Amm CA, El-Musa KA. Management of acute and chronic open wounds: the importance of moist environment in optimal wound healing. Curr Pharm Biotechnol 2002;3:179-95.

4. Katiyar C, Gupta A, Kanjilal S, Katiyar S. Drug discovery from plant sources: an integrated approach. Ayu 2012;33:10-9.

5. Ghosh PK, Gaba A. Phyto-extracts in wound healing. J Pharm Pharm Sci 2013;16:760-820.

6. De Wet H, Van Wyk BE. An ethnobotanical survey of southern African Menispermaceae. S Afr J Bot 2008;74:2-9.

7. Chi S, She G, Han D, Wang W, Liu Z, Liu B. Genus Tinospora: ethnopharmacology, phytochemistry, and pharmacology. Evid Based Complementary Alternat Med 2016. DOI:10.1155/2016/9232593

8. Barua C, Talukdar A, Barua A, Chakraborty A, Sarma RK, Bora RS. Evaluation of the wound healing activity of methanolic extract of Azadirachta Indica (Neem) and Tinospora cordifolia (Guduchi) in rats. Pharmacologyonline 2010;1:70-7.

9. Meravanige G, Kamdod MA. Effect of topical Tinospora cordifolia on excisional wound in albino rats. Int J Pharm Biol Sci 2012;2:25-9.

10. Meravanige G, Kamdod MA. Effect of topical Tinospora cordifolia on healing of burn wounds in wistar rats. Int J Pharm Biol Sci 2012;3:351-8.

11. Nema A, Gupta N, Jain UK. Evaluation of wound healing activity of Tinospora cordifolia willd. Der Pharm Sin 2012;3:126-30.

12. Ramachandra YL, Kavitha BT, Rai PS, Vedamurthy AB, Shruthi SD. Investigation of wound healing activity of extracts from Tinospora cordifolia. Deccan J Pharmacol 2011;2:43-53.

13. Meravanige G, Priyadarshini K. Influence of Tinospora cordifolia on wound healing in albino rats. Int J Pharm Biol Sci 2012;3:379-84.

14. Hashilkar NK, Patil PA, Bagi JG, Patil SY, Angadi NB. Influence of Tinospora cordifolia on wound healing in wistar rats. Int J Basic Clin Pharmacol 2016;5:923-8.

15. Singh AK, Om Preethi B, Singh HN, Gangwar AK, Niyogi D, Sangeeta Devi KH. Comparative evaluation of the wound healing potential of Tinospora cordifolia and its combination with local insulin therapy in diabetic rabbits. J Pharmacogn Phytochem 2017;6:1812-7.

16. Abood WN. Immunomodulatory, gastroprotective and wound healing potential of malaysian medicinal plants (Phaleria macrocarpa and Tinospora crispa). [thesis]; 2014.

17. Vijendren S. Assessment of in vitro wound healing activity of the Tinospora crispa extracts. Int J Pharmacol Pharm Technol 2017;1:1-5.

18. Guo S, DiPietro LA. Factors affecting wound healing. J Dent Res 2010;89:219-29.

19. Thakur R, Jain N, Pathak R, Sandhu SS. Practices in wound healing studies of plants. J Evid Based Complementary Alternat Med 2011. https://doi.org/10.1155/2011/438056

20. Upadhyay AK, Kumar K, Kumar A, Mishra HS. Tinospora cordifolia (Willd.) Hook. f. and thoms. (Guduchi)-validation of the ayurvedic pharmacology through experimental and clinical studies. Int J Ayurveda Res 2010;1:112-21.

21. Sangeetha MK, Balaji Raghavendran HR, Gayathri V, Vasanthi HR. Tinospora cordifolia attenuates oxidative stress and 
distorted carbohydrate metabolism in experimentally induced type 2 diabetes in rats. J Nat Med 2011;65:544-50.

22. Shiddamallayya N, Azra Yasmeen, Gopakumar K. Hundred common forest medicinal plants of Karnataka in primary healthcare. Indian J Tradit Know 2010;9:90-5.

23. Neamsuvan O, Madeebing N, Mah L, Lateh W. A survey of medicinal plants for diabetes treating from chana and nathawee district, songkhla province, Thailand. J Ethnopharmcol 2015;174:82-90.

24. Silambarasan R, Ayyanar M. An ethnobotanical study of medicinal plants in palamalai region of Eastern Ghats, India. J Ethnopharmacol 2015;172:162-78.

25. Srivastava TN, Rajasekharan S, Badola DP, Shah DC. An index of the available medicinal plants, used in Indian system of medicine from Jammu and Kashmir state. Anc Sci Life 1986;6:49-63.

26. Mishra R, Kaur G. Aqueous ethanolic extract of Tinospora cordifolia as a potential candidate for differentiation based therapy of glioblastomas. PLoS One 2013;8:e78764.

27. Pandey M, Chikara SK, Vyas MK, Sharma R, Thakur GS, Bisen PS. Tinospora cordifolia: a climbing shrub in health care management. Int J Pharma Bio Sci 2012;3:612-28.

28. Sharma N, Kumar A, Sharma PR, Qayum A, Singh SK, Dutt P, et al. A new clerodane furano diterpene glycoside from Tinospora cordifolia triggers autophagy and apoptosis in HCT-116 colon cancer cells. J Ethnopharmacol 2018;211:295-310.

29. Purandare $\mathrm{H}$, Supe A. Immunomodulatory role of Tinospora cordifolia as an adjuvant in surgical treatment of diabetic foot ulcers: a prospective randomized controlled study. Indian J Med Sci 2007;61:347-55.

30. Jayaseelan C, Gandhi PR, Rajasree SRR, Suman TY, Mary RR. Toxicity studies of nanofabricated palladium against filariasis and malaria vectors. Environ Sci Pollut Res 2018;25:324-32.

31. Duraipandiyan V, Ignacimuthu S. Antifungal activity of traditional medicinal plants from Tamil Nadu, India. Asian Pac J Trop Biomed 2001;1(2, Suppl):S205-S215.

32. Agarwal A, Malini S, Bairy KL, Rao M. Effect of Tinospora cordifolia on learning and memory in normal and memory deficit rats. Indian J Pharmacol 2002;34:339-49.

33. Grover JK, Vats V, Rathi SS. Anti-hyperglycemic effect of Eugenia jambolana and Tinospora cordifolia in experimental diabetes and their effects on key metabolic enzymes involved in carbohydrate metabolism. J Ethnopharmacol 2000;73:461-70.

34. Wadood N, Wadood A, Shah SAW. Effect of Tinospora cordifolia on blood glucose and total lipid levels of normal and alloxandiabetic rabbits. Planta Med 1992;58:131-6.

35. Rani J, Singh L, Singh H, Kapoor M, Singh G. Preliminary phytochemical analysis of different solvent extracts from leaf and stem of Tinospora cordifolia. Int J Phytother 2015;5:124-8.

36. Lang Q, Wai CM. Supercritical fluid extraction in herbal and natural product studies-a practical review. Talanta 2001;53:771-82.

37. Premanath R, Lakshmidevi N. Studies on anti-oxidant activity of Tinospora cordifolia (Miers.) leaves using in vitro models. J Am Sci 2010;6:736-43.

38. Upadhyay N, Ganie AS, Agnihotri RK, Sharma R. Studies on antioxidant activity and total phenolic content of Tinospora cordifolia (Miers.) stem using in vitro models. Am J Phytomed Clin Ther 2013;1:617-27.

39. Ahmad W, Jantan I, Bukhari SNA. Tinospora crispa (L.) hook. f. and thomson: a review of its ethnobotanical, phytochemical, and pharmacological aspects. Front Pharmacol 2016;7:59.

40. Koay YC, Faheem A. A review of the secondary metabolites and biological activities of Tinospora crispa (Menispermaceae). Trop J Pharm Res 2013;12:641-9.

41. Pranee C, Aimmanus A, Anchalee A, Pranee C. Toxicological study of crude extract of Tinospora crispa miers ex hook F. and thoms. Thai J Pharm Sci 1997;21:199-210.

42. Kadir MF, Bin Sayeed MS, Setu NI, Mostafa A, Mia MM. Ethnopharmacological survey of medicinal plants used by traditional health practitioners in Thanchi, Bandarban Hill Tracts, Bangladesh. J Ethnopharmacol 2014;155:495-508.

43. Apriandanu D, Yulizar Y. The role of aqueous leaf extract of Tinospora crispa as reducing and capping agents for synthesis of gold nanoparticles. IOP Conf Ser Mater Sci Eng 2017;188:012013.

44. Rawal A, Muddeshwar M, Biswas S. Effect of Rubia cordifolia, Fagonia cretica linn, and Tinospora cordifolia on free radical generation and lipid peroxidation during oxygen-glucose deprivation in rat hippocampal slices. Biochem Biophys Res Commun 2004;324:588-96.

45. Ilaiyaraja N, Farhath Khanum. Antioxidant potential of Tinospora cordifolia extracts and their protective effect on oxidation of biomolecules. Phcog J 2011;3:56-62.

46. Levine RL, Garland D, Oliver CN, Amici A, Climent I, Lenz AG, et al. Determination of carbonyl content in oxidatively modified proteins. Methods Enzymol 1900;186:464-78.

47. Polu PR, Nayanbhirama U, Khan Saleemulla, Maheswari R. Assessment of free radical scavenging and anti-proliferative activities of Tinospora cordifolia miers (Willd). BMC Complement Altern Med 2017;17:457.

48. Joshi G, Kaur R. Tinospora cordifolia: a phytopharmacological review. Int J Pharm Sci Res 2016;7:890-7.

49. Kattupalli S, Vesta V, Vangara S, Spandana U. The multi-activity herbaceous vine-Tinospora cordifolia. Asian J Pharm Clin Res 2019;12:23-6.

50. Amom Z, Azman KF, Ismail NA, Shah ZM, Arshad MSM. An aqueous extract of Tinospora crispa possesses antioxidative properties and reduces atherosclerosis in hypercholesterolemic-induced rabbits. J Food Biochem 2011;35:1083-98.

51. Ibrahim MJ, Wan-Nor I'zzah WMZ, Narimah AHH, Nurul Asyikin Z, Siti-Nur Shafinas SAR, Froemming GA. Anti-proliperative and antioxidant effects of Tinospora crispa (Batawali). Biomed Res 2010;22:57-62.

52. Cavin A, Hostettmann K, Dyarmyko W, Potterat O. Antioxidant and lipophilic constituents of Tinospora crispa. Planta Med 1998;64:393-6.

53. Fonder MA, Lazarus GS, Cowan DA, Aronson Cook B, Kohli AR, Mamelak AJ. A practical approach to the care of nonhealing wounds and wound care dressings. J Am Acad Dermatol 2008;58:185-206.

54. Zhao R, Liang H, Clarke E, Jackson C, Xue M. Inflammation in chronic wounds. Int J Mol Sci 2016;17:2085.

55. Jeon IH, Kim HS, Kang HJ, Lee HS. Jeong SI, Kim SJ, et al. Antiinflammatory and antipruritic effects of luteolin from perilla $(P$. frutescens L.) leaves. Molecules 2014;19:6941-51.

56. Alderton WK, Copper WK, Knowles RG. Nitric oxide synthases: structure, function and inhibition. Biochem J 2001;357:593615.

57. Jung WK, Choi I, Lee DY, Yea SS, Choi YH, Kim MM, et al. Caffeic acid phenethyl ester protects mice from lethal endotoxin shock and inhibits lipopolysaccharide-induced cyclooxygenase- 2 and inducible nitric oxide synthase expression in RAW 264.7 macrophages via the p38/ERK and NF-kappaB pathways. Int J Biochem Cell Biol 2001;40:2572-82.

58. Nakanishi M, Rosenberg DW. Multifaceted roles of PGE2 in inflammation and cancer. Semin Immunopathol 2013;35:12337.

59. Philip S, Tom G, Vasumathi AV. Evaluation of the antiinflammatory activity of Tinospora cordifolia (Willd.) miers chloroform extract-a preclinical study. J Pharm Pharmacol 2018;70:1113-25.

60. Ghatpande NS, Misar AV, Waghole RJ, Jaadhav SH, Kulkarni PP. Tinospora cordifolia protects against inflammation associated anemia by modulating inflammatory cytokines and hepcidin expression in male Wistar rats. Sci Rep 2019;9:10969.

61. Chen L, Gua S, Ranzer MJ, DiPietro LA. Toll-like receptor 4 has an essential role in early skin wound healing. J Invest Dermatol 2013;133:258-67.

62. Abood WN, Fahmi I, Abdulla MA, Ismail S. Immunomodulatory effect of an isolated fraction from Tinospora crispa on intracellular expression of INF- $\gamma$, IL-6 and IL-8. BMC Complement Altern Med 2014;14:205.

63. Adnan AZ, Taher M, Afriani T, Fauzana A, Roesma DI, Putra AE. Anti-inflammatory activity of tinocrisposide by inhibiting nitric oxide production in lipopolysaccharides-stimulated RAW 264.7 cells. Asian J Pharm Clin Res 2018;11:149-53. 
64. Ricard Blum S, Ruggiero F. The collagen superfamily: from the extracellular matrix to the cell membrane. Pathol Bio (Paris) 2005;53:430-42.
65. Caley MP, Martins VLC, O’Toole EA. Metalloproteinases and wound healing. Adv Wound Care (New Rochelle) 2015;4:22534. 